\title{
Cultutal Factors Affecting English Proficiency in Rurl Areas
}

\author{
Ee Chop Ler \\ (Universiti Darul Iman Malaysia, Malaysia) \\ doi:10.7575/aiac.alls.v.3n.1p.1
}

\begin{abstract}
The purpose of this study is to investigate the rural 'cultural 'problems and to determine their effect on the learning of English. Twenty students from different ethnic backgrounds and English language proficiency in six rural schools in Terengganu, Malaysia were interviewed. In addition the teachers also from different rural schools and ethnic backgrounds responded to a questionnaire. The problems discussed by both the teacher and student respondents arose due to the rural cultural setting. The findings of this study show that 1) five major problem areas exist, namely peer pressure and motivation, attitudes towards English, teaching methodology, school culture ,influence of Islamic teaching on the learning of English 2) the problems discussed by the teachers and students are similar and 3) most importantly all these identified problems are closely related to the rural setting. Therefore, one can conclude that rural cultural factors adversely affect English Proficiency of the rural students of this study.
\end{abstract}

\section{Background}

The fall in the standard of English in Malaysia is evidenced in all public examinations like UPSR (Ujian Pencapaian Sekolah Rendah examination), PMR (Penilaiaan Menengah Rendah) and SPM (Sijil Pelajaran Malaysia). Probably, a pass in English has never been made compulsory for SPM. Since 2000, a pass in Bahasa Melayu was sufficient to get the SPM certificate. In fact, the English result in major examinations 'hovers at a low level of around $60 \%$ candidates achieving passes' since 2000. The poor performance in English marred an otherwise marginally better performance in the 2000 Ujian Pencapaian Sekolah Rendah (UPSR) examination (The Star, 8.11.2000). Furthermore, the percentage of passes in English among rural students is only $49.6 \%$ compared to urban students $(72.8 \%)$.

\section{The status and role of English}

With Bahasa Melayu as the medium of instruction since 1970, the status of English has become that of a 'second language'. A prominent local linguist Asmah (1992, p.66) states the 
role of the Bahasa Melayu is for 'nationalism' while English is for 'nationism'. The former is for national unity and identity while the latter is for maintaining group cohesion and political ties among Malaysians.

\section{Concern for the standard of English}

It is clear then all Malaysians recognize the importance of English. New graduates face a serious problem in English (The Star 12.7.2000). A majority of Malaysians (90\%) entering local universities have insufficient English proficient for study purposes, 44\% classified as weak while 19\% are very weak in the subject (The New Straits Times 12.9.2000). These graduates will have tougher time getting a job if they are not proficient in English and will definitely 'lose to other applicants'. It was found these graduates struggle to speak English in job interviews (The Star 10.2. 2000). Several reasons explain this decline such as the switch from English to Malay as the medium of instruction in schools to limited exposure and use of English. This greatly affected the motivation to learn English especially in rural areas. Besides, English has low status in public exams as it is not essential to pass English. In addition English is not offered at STPM level (Sijil Tinggi Pelajaran Malaysia) or preuniversity level. Thirdly the poor proficiency of teachers in English adds to the poor performance. Young English teachers are struggling with their own proficiency in English, and this is reiterated by many parents, who question the proficiency of young English teachers in schools (The Star, 22.12.2000). Fourthly, students lack self motivation and initiative to communicate in English as they resort to their respective native languages as means of effective communication.

\section{Objectvies}

The objectives of the study are 1) to obtain empirical data of the relationship between English proficiency of the student and the 'rural cultural factors' and 2) to provide suggestions to improve the proficiency in English among rural students.

\section{Definitions of terms}

\section{Language proficiency}

It is the ability to speak, write and understand the target language. It is measured by the students' scores in PMR, the Cloze (Fotos, 1991) and Error Identification test. Then the proficiency level is defined using the scale of the Reading Test from the Ministry of Education. 


\section{Second Language (L2)}

It refers to the language learned after the mother tongue is acquired e.g. English after Bahasa Melayu.

\section{Rural schools}

In Malaysia they are schools located in towns or districts having a population of less than 10,000 (Rosli \& Malachi, 1990).

\section{Attitude}

It is a set of beliefs learners have towards the use and learning of the target language or towards the speakers of that language.

\section{Motivation}

According to Gardner (1985, p.10), it is the "combination of effort and desire to achieve the goal of learning the language including favorable attitudes towards learning the language'.

\section{Exposure, language environment and use of language}

They refer to the sum total of contacts with the target language. Mackay (1965) classified language exposure into three namely; personal contact with members of family, non personal contact through media and non personal contacts through written forms. Language environment, according to Dulay, Marina, and Stephen (1982), encompasses everything the language learner hears and sees in the new language.

Peers

They are groups of individuals of the same age group of children or adolescents sharing same interests and able to communicate and interact freely in school.

\section{Rural society}

It refers to all members in a group staying together in a rural area whose patterns of behavior are learned and passed down to the future generation. 


\section{Culture}

It is the totality of socially transmitted behavior patterns, beliefs, institutions and traits considered as the expression of a particular community.

\section{Review of the related literature}

Language learning involves a complex interplay of personal and social variables such as motivation and attitude toward learning English, limited exposure to the target language and peer influence. (See Figures 1 \& 2) Gardner and Lambert (1959) show how success in language learning is related to attitudinal variables like attitudes towards the language learned and towards the speakers of that language and culture. Spolsky (1969) also studies the relationship between proficiency of second language and attitude of the students towards the language learnt of 315 foreign students from different backgrounds studying in America and discover a relationship between the attitudes of the students towards English and their grades. However local studies by Jayatilaka (1982) studies 132 second year students in Universiti Sains Malaysia (USM) finds a negative attitude held by some of the students towards the learning of English does not adversely affect successful second language learning. Similarly Chandrasegaran (1979) studies the upper Secondary Malay medium students show low correlation between proficiency and attitude towards English Learning.

Motivation can also be considered a good predictor of success in second language learning. Gardner\& Lambert (1979) equated integrative motivation as necessary for the mastery of language proficiency. Thevanathampillai and Baba's (1984) extensive study on 295 fifth formers or Grade students taken from 7 schools in Fiji shows a significant correlation between the intensity of motivation and proficiency level. Students with greater motivational intensity perform better compared to students with low intensity. Other factors include exposure to target language, SES (Socio economic status), parental attitude, peer influence role of teachers and shyness factor.

\section{Methodology}

Semi structured interviews (using open ended questions) with twenty students as well as ten teachers from six rural schools in Terengganu are carried out 


\section{Research design}

In this research, the English language proficiency is the first variable and measured by PMR results and a proficiency test (adapted by the researcher) and the other variables include rural attitudes towards English, peer pressure motivation, rural school culture, teaching methodology and the effect of religion called rural cultural factors as the second variable.

First variable - English Proficiency (PMR \& Cloze test)

Second variable- Rural cultural factors

\section{Subjects}

Twenty student respondents coming from different socioeconomic backgrounds studying in six rural schools are randomly selected as subjects. They are interviewed for an hour as they take English for the public exam. (Appendix A) As for the teacher respondents, ten teachers of different academic qualifications and years of teaching experience are also randomly chosen. They were asked to respond to the given questionnaire. (Appendix B)

\section{Research tool}

Semi structured interviews sessions were carried out for the students while the teachers were given a questionnaire. The interview sessions were carried out in an informal manner sitting under a tree in a school compound over four weekends to create a non threatening atmosphere. Each student met the researcher for an hour.

Cloze tests, a global text of English proficiency (Darnell 1968, Oller1872, Spolsky 1968, Stubbs and Tucker 1974 cited in Foto 1991) and Error identification questions were used to measure the proficiency of the 20 student respondents. (Appendix C) The teachers favored the use of the questionnaire as they preferred to write down their opinion. Their response serves to cross validate the findings from the students' interviews (a similar methodology used by Patton, 1996).

\section{Methods of data analysis}

The method of data analysis used for this study comprises of the following steps:

i) Analysis of data from student respondents (Interview)

ii) Analysis of data from the teacher respondents (Questionnaire)

iii) Making a connection between the rural cultural variables 
The proficiency test of the student respondents shows seven students obtained 10-20 marks,3 students obtained 21-30,two student respondents scored marks ranging from 31-40,another two obtained marks from 41-50, two scored 51-60 while three students scored marks from 6170 and finally one student obtained 71-80 marks.

\section{Table 1: Proficiency grade of student respondents (based on Reading Program Scale)}

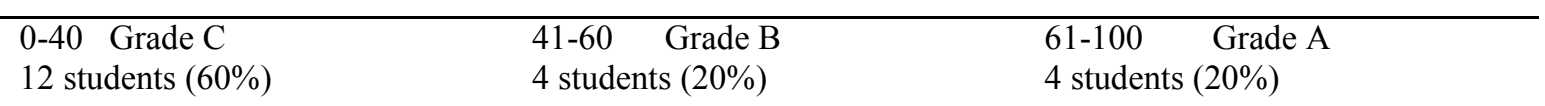

When using the class Reading Program scale, Table 1 shows 12 students fall in the Grade C category, 4 in Grade B while another 4 in Grade A. In other words, $60 \%$ of the student respondents are not very proficient, $20 \%$ are in the middle proficiency level and another $20 \%$ can be considered proficient as they obtained Grade A in the test. As for their PMR results, only 3 students scored A, 6 obtained B while 11 got Grade C.

Since the view of the teachers and students are fairly similarly, the identified responses with regards to problems in learning English in the rural setting will be analyzed together. This section will consist of 1) the analysis of the views and suggestions of the student and teacher respondents and 2) compares the views expressed to the features of rural settings

\section{Analysis of the students and teachers' views}

Analysis of the students' perception of the importance of learning English

All the twenty students (100\%) agreed that English is important as a world language, for further education, to pass exam for professional courses, get scholarship for travelling purposes and to seek jobs. As for the teachers' perception all also agreed on the importance of English.70\%, feel that English is needed greatly in universities as reference books are in English, $65 \%$ as world language, $40 \%$ for professional courses, $20 \%$ to obtain scholarships, $10 \%$ mention English for travelling purposes, $10 \%$ to seek jobs and $5 \%$ relates the importance of English with exams.(Table 2)

Teachers' perception of the importance of learning English

All the 10 teacher respondents agree that English is important and cannot be underestimated.80\% of the teacher respondents feel English is greatly needed in universities 
especially as most of the reference books are in English.8 teachers state that English is also a language of international communciation. $20 \%$ associate it with international traveling, $10 \%$ relates the importance of English with examinations while $10 \%$ for the acquisition of knowledge. Therefore, it is clear that all teachers reiterated the importance of English.

\section{Students' attitude towards the learning of English}

$60 \%$ feel it should be made compulsory. $15 \%$ describe that science is more important. $10 \%$ feel that it is difficult to learn writing and vocabulary as they lack the necessary study skills to excel in the acquisition of English.10\% mentioned the problem of boring lessons.

\section{Table 2: Students attitude towards the learning of English}

\begin{tabular}{llc}
\hline Views learning English & Number of students & $\mathbf{\%}$ \\
\hline 1.Important to learn & 12 & $60 \%$ \\
2.Unimportant to learn & 3 & $15 \%$ \\
3.Dislike learning English & 2 & $10 \%$ \\
4.Difficult to learn & 2 & $10 \%$ \\
5.Boring classes/ exercises & 2 & $10 \%$ \\
6.Learn to pass exams & 2 & $10 \%$ \\
\hline
\end{tabular}

\section{Teachers' attitude towards the teaching and learning of English}

Table 3 shows $100 \%$ agree that there is a need to study English. One teacher respondent mentions it is an asset. Other terms used by teacher respondents concerning the need to learn English are 'crucial' and 'necessary', 'should be encouraged' 'very important'.

Table 3: Views on teaching of English

\begin{tabular}{lll}
\hline Views on teaching of English & Number & \% \\
\hline Should be emphasized & 1 & $10 \%$ \\
Made compulsory & 4 & $40 \%$ \\
Very Important & 5 & $50 \%$ \\
\hline
\end{tabular}

\section{How student respondents studied English}

Table 4 shows all the twenty students learn English in a classroom setting. They have to depend on their English teachers to provide intensive drills; class projects and English activities.20\% read on their own to improve their English and learn new things about language. $10 \%$ attend tuition classes. Other ways are self study, vocabulary exercises, speaking with friends and listening to radio programs. 
Table 4: How student respondents studied English

\begin{tabular}{lll}
\hline Ways of learning & Number of students & \% \\
\hline Class activities/exercises & 20 & 100 \\
Reading & 4 & 20 \\
Sentence/vocabulary & 2 & 10 \\
Pressured by teachers & 2 & 10 \\
Tuition & 2 & 10 \\
Other ways.eg. radio etc & 2 & 10 \\
Speaking with friends & 1 & 10 \\
Self study & 1 & 5 \\
\hline
\end{tabular}

Problems in learning English according to student respondents

When asked about problems in learning English, the student respondents tend to blame the non supportive school culture towards the learning of English. According to them, there is no support from the authorities followed by $80 \%$ of the students who feel that the negative attitude of the students is another reason.75\% mention lack of an English speaking environment as another factor. Others include boring teaching methods (30\%) and English unimportant compared to Science and Mathematics (20\%).It is clear that a non supportive culture, lack of English speaking environment and a negative attitude to English are the major problems associated with the learning of English. (Table 5)

Table 5: Problems in learning English according to student respondents

\begin{tabular}{lll}
\hline Problems & Number & $\mathbf{\%}$ \\
\hline Non supportive school culture & 20 & 100 \\
Negative attitude & 16 & 80 \\
Lack English environment & 15 & 75 \\
Lack motivation & 10 & 50 \\
Boring teaching methods & 6 & 30 \\
Science \& Mathematics more important & 4 & 20 \\
\hline
\end{tabular}

Problems in learning and teaching of English as perceived by the teachers

Table 6 show the negative attitude of the students, lack of an English speaking environment, boring teaching methods as well as non-supportive school culture are the main problems perceived by the teachers. Like many student respondents, teachers also feel that a need to vary teaching methods and techniques. It is clear that if innovative methods are used, there is a fear of negative reaction from rural students for example drama. The rural people considered it 'unIslamic' to stage an English drama as there is a difference between western and eastern values. Moreover the teaching methods employed like language drills, grammar quizzes in classes are examination based. One teacher expressed that "at the end of the day, people are going to judge you on your student achievement'. Therefore it is safer to use examination approach technique than games and fun filled activities. 
Table 6: Problems in learning and teaching of English as perceived by the teachers

\begin{tabular}{lll}
\hline Problems & Number & $\mathbf{\%}$ \\
\hline Student attitude & 10 & 100 \\
Lack of motivation & 5 & 50 \\
Lack of exposure & 1 & 10 \\
Boring teaching methods & 10 & 100 \\
Non supportive school culture & 10 & 100 \\
Science \& Mathematics more important & 2 & 20 \\
Government policy on English & 6 & 60 \\
Rural thinking & 1 & 10 \\
Use of Bahasa Melayu & 5 & 50 \\
Red Tape & 2 & 20 \\
Political reasons & 1 & 10 \\
Difficult to teach & 1 & 10 \\
Low proficiency & 1 & 10 \\
Parental role & 1 & 10 \\
\hline
\end{tabular}

Different methods used by teacher respondents

Table 7: Different methods used by teacher respondents

\begin{tabular}{llll}
\hline Drills & Exam exercises & Group work & Others(Creative methods etc) \\
$5(50 \%)$ & $5(50 \%)$ & $1(10 \%)$ & $2(20 \%)$ \\
\hline
\end{tabular}

Both the teachers and students therefore agreed that there is a need to introduce a variety of more creative activities in classes like movies, less examination oriented exercises so as to arouse the interest of the students. (Table 7) When asked further on the problems of teaching of English in the rural areas, two teachers stress that it is difficult, challenging, time consuming to teach English in rural setting. They compare the teaching of English to 'fighting in a battlefield"' So while the teachers think it is tiring, the students think it is boring.

Common problems reported by students and teacher respondents

Table 8: Common problems reported by student and teacher respondents

\begin{tabular}{llcccc}
\hline \multicolumn{1}{c}{ Problems } & $\begin{array}{c}\text { Students' } \\
\text { number }\end{array}$ & $\begin{array}{c}\text { Student } \\
\mathbf{( \% )}\end{array}$ & $\begin{array}{c}\text { Teachers' } \\
\text { number }\end{array}$ & $\begin{array}{c}\text { Teacher } \\
(\%)\end{array}$ \\
\hline 1. & Negative attitude of students & 16 & 80 & 10 & 100 \\
2. & Lack of motivation & 10 & 50 & 5 & 50 \\
3. & Unsupportive school culture & 20 & 100 & 10 & 100 \\
4. & Boring teaching methods & 6 & 30 & 10 & 100 \\
5. & English unimportant & 20 & 100 & 6 & 60 \\
6. & Science \& Mathematics more important & 8 & 40 & 20 & 20 \\
\hline
\end{tabular}

$80 \%$ feels that the stumbling block towards the learning is the attitude of their peers (See Table 8).The students are shy for fear of making grammatical mistakes and therefore unwilling to speak. Teasing among peers is rampant and to avoid embarrassment (malu or segan); their response is to be silent as well as face saving to avoid conflicts as well as 
maintain personal integrity. They are often teased when attempting to speak English hence prefer to code-switch (mixing two languages when speaking or mixing English with their mother tongue) for the sake of solidarity to avoid conflict and maintain social harmony. In rural setting too, negative beliefs passed down from their grandparents regarding the colonial culture do to some extent influence their attitude in wanting to learn English.

\section{Lack of exposure}

Table 9: Lack of exposure

\begin{tabular}{lll}
\hline Media for Exposure & Number & $\mathbf{\%}$ \\
\hline Books & 20 & 100 \\
Movies/DVD & 20 & 100 \\
Others-cyber cafes, student exchange program & 20 & 100 \\
\hline
\end{tabular}

Table 9 shows all students agreed on the need for exposure to the English language regardless of whether in written or oral form e.g. English books and movies. English movies have unhealthy Malay subtitles. The student respondents feel other ways of exposures like cyber cafes and program student exchange are lacking. Another finding is the lack of infrastructure and facilities in the rural areas.5 out of 20 students (Table 10) talk about the location from Kuala Lumpur which may cause problems. Besides, it means higher prices of books and teaching aids. English movies are rarely screened as there is no theatre. Besides they are associated with violence and fights and are considered aggressive anti rural, anti religion and anti Islamic.

Table 10: Differences in characteristics between the urban and rural areas in learning environment perceived by the students

\begin{tabular}{lll}
\hline Characteristics & Number & $\mathbf{\%}$ \\
\hline Lack of English speaking environment & 13 & 65 \\
Distance from the English speaking towns & 5 & 25 \\
Lack of exposure e.g. books English VCD & 4 & 20 \\
Negative student attitude & 4 & 20 \\
Lack of facilities' & 3 & 15 \\
English as foreign language & 1 & 5 \\
\hline
\end{tabular}

Table 11: Students' perception on whom to blame for the low proficiency in English in rural areas

\begin{tabular}{lll}
\hline Who is to be blamed & Number & \% \\
\hline Students \& Peers & 13 & 65 \\
School authorities & 10 & 50 \\
Rural environment & 3 & 15 \\
Society/parents & 2 & 10 \\
Others & 1 & 5 \\
\hline
\end{tabular}


Students' perception on whom to blame for the low proficiency in English in rural areas

$65 \%$ of the student respondents feel that the school authorities, the students, teachers as well as the rural society should be blamed for the poor proficiency in English among rural students (Table 11). The school authorities must set good examples to speak English and create a more suitable school culture to motivate language learning. The principal, teachers and non academic staff are unable to speak English hence find it difficult to encourage students.

Students' perception of the role of rural cultural factors in learning English

Table 12: Students' perceptions of the role of rural cultural factors in learning English

\begin{tabular}{llc}
\hline Rural cultural factors & Number & $\mathbf{\%}$ \\
\hline Yes (Agree) & 19 & 95 \\
No(Disagree) & 1 & 5 \\
\hline
\end{tabular}

Table 4.12, shows all student and teacher respondents agree that the rural cultural setting is a problem. $95 \%$ of the students agree that the school culture in the rural area discourages the learning of English.20\% feel that the teachers have a role to stress the importance and propagate the use of English. The teachers blame the school authorities for not only encouraging the setting up of an English speaking environment but also cause the failure in the planning of effective English programs.

Table 13: Other variables that result in problems in learning English

\begin{tabular}{|c|c|c|c|c|}
\hline Problems & Student & $\%$ & Teacher & $\%$ \\
\hline 1. Role of Malay Language & 7 & 35 & 5 & 50 \\
\hline 2. Red Tape & - & - & 2 & 20 \\
\hline 3. Political reasons & 4 & 20 & 1 & 10 \\
\hline 4. Low proficiency & - & - & 1 & 10 \\
\hline 5. Attitude of teachers & 1 & 5 & - & - \\
\hline 6. Attitude of non academic staff & - & - & 1 & 10 \\
\hline 7. Society & - & - & 8 & 80 \\
\hline 8. Lack of study skills & 4 & 20 & - & 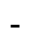 \\
\hline 9. Distance/Infrastructure & 5 & 25 & - & - \\
\hline 10. Lack of parental support & - & - & 2 & 20 \\
\hline
\end{tabular}

Other variables that result in problems in learning English

The widespread use of Bahasa Melayu is one reason expressed by both the student and teacher respondent for the poor proficiency of English among rural students (Table 13). Half the teachers feel there is a conflicting role in the part played by Malay as the first language and English as the second language or even third language. The ease in the use of the first language discourages the use of English which is rarely used. Another view expressed by the teacher respondents is the present political situation where the government has to gain support 
by retaining the use of Bahasa Melayu.10\% lack study skills in learning English .4 students feel it is hard to learn English compared to Science and Mathematics.

From the above analysis one can notice that all the identified problems given by all respondents are somehow closely related to the rural scenario. It is the rural setting, traits practices and culture that give rise to the problems, causing the low proficiency of English. To conclude one can say that the rural cultural setting does affect the proficiency level of English among the students in rural schools.

\section{Recommendations to resolve the identified problems}

One can discuss the recommendations for the five problems found in this study. 1) The negative attitude towards the learning of English of the rural students 2) Peer pressure and lack of motivation 3) Teaching methodology 4) The lack of an English speaking environment and limited exposure and 5) A non supportive school culture.

\section{The role of the students}

Students need to change their negative attitude towards the learning of English to a positive one. Rural students consider the use of English as unpatriotic. This misconception must be corrected. More activities can be used to encourage them to speak English e.g. announcements in school be in English, English logbooks, Vocabulary Contest, Spelling bee, English mail, English sketch and educational trips. Students should take the initiative to lead and not wait for English teachers to suggest ideas. The school authorities can guide them and help change their negative attitude. Streaming the students into equal linguistic abilities can help students to learn better as shyness factor (Zimbardo, 1977) is prevalent among rural students.

\section{The role of teachers}

The teachers are the best personnel to counsel and help students e.g. in class, these students lack study skills hence teachers must make sure their explanations are clearer. Besides, the teachers must be proficient in all the four skills. Unfortunately there are insufficient English teachers in rural schools hence it is common to find non English majors i.e. conversion teachers from other subjects to teach English. Language learning is not merely the accumulation of knowledge but the building up of linguistic skills hence it is better to teach the correct grammatical skills than to let the students relearn and reconstruct the errors learnt 
from non-TESL teachers. According to a retired UKM lecturer "only 30\% of TESL students are qualified to teach English as most of them 'can't even string together a proper sentence (The Sunday Star, 28.1.2000).

\section{The role of the parents}

Like the teachers, parents can help motivate and create a need to use English for example, short English conversations. They must get rid of the belief of negative colonial rule, an exclusively rural cultural trait and set good example to speak English.

\section{The peer pressure and lack of motivation}

The rural students are also influenced by the narrow-mindedness and shyness mentality of their peers, typical of limited exposure. According to Musgrave (1972) and Murdock (1965) peers are capable of influencing each other. English teachers can implement punishments and a fine system to curb the 'teasing, jeering, laughing and shyness culture' (a rural cultural feature) among the peers, hence monitoring the reactions of students when their peers speak English.

\section{Teaching methodology}

The teacher respondents found difficulty in using the innovative teaching methods while the student respondents felt strongly that their poor proficiency results from the boring techniques used. According to Gill (The Star 10.11 2000), uninspiring and conventional styles of teaching will kill students 'interest resulting in students not learning.' Teachers are expected to be 'actors' and each performance must interest the audience so as to create a conducive proactive learning environment. New teaching approaches can incorporate the use of computers, educational visits, dramas, movies \& games can be exploited. For rural students,

silence is one of their major cultural traits (Bahiyah, 1992) either to show politeness or for group solidarity and it can be overcome by asking them to speak more. Zimbardo (1977) asserted that shyness is negative in language learning and in rural schools this is true. 


\section{The influence of the ruling Islamic government}

Since the government stresses on Islamic teaching, this does have effects on the learning of English. The students are influenced by the traditional beliefs handed by their grandparents e.g. the association of English with yellow culture. Rural life centered on religious beliefs. Rural students should be made aware that learning a foreign language is not forbidden in the religion.

\section{Non supportive school culture \& setting}

Rural school culture which includes non-English speaking environment, negative attitude of the school administrators, lack of educational facilities, the greater importance given to Science and Mathematics must be given attention.

\section{Lack of an English speaking environment}

All the respondents mentioned the lack of a favorable environment to inhibiting the learning of English. One can create this English environment by conducting English assembly. The library, the tuck-shop and 'Balai English' or English Hall can be centers for English so students can read. English tables in tuck-shop can convert the 'fear' into 'love' culture. English Day can be made compulsory encompassing all staff, academic and non academic staff in school

\section{Attitude of the school administrators}

The school culture is created by teamwork of students, teachers and the school administrators. If each and every member of the school plays his part in encouraging the use of English, then the school culture will be conducive. However all respondents feel that the rural school culture is negative and non conducive towards the learning of English.

\section{Priority given to Science and Mathematics}

All the respondents agree that Science and Mathematics are more important than English. One good suggestion is to remind them that without English one just cannot proceed in the Science and Mathematics at tertiary level. It is true that engineers need mathematics but without good English, they will encounter difficulties in doing research and practice. One good recommendation is to make either a pass or even a credit in English a compulsory entrance criterion for entry into Science and Mathematics courses in universities. 


\section{Lack of facilities}

This study points out lack of physical and educational facilities due to the distance away from English speaking towns is another problem. New innovations take time to be transferred. The educational authorities should be aware of the need for a pool of proficient English teachers. Entry requirement to English training course must be raised as we cannot have English teachers speaking improper English. Usually 'mediocre' teachers (The Sunday Star 12.9.2000) will produce mediocre students. As for the vernacular schools, students have to master three languages at the same time that is after Malay, English and their mother tongue of Tamil or Mandarin. There is bound to be a lot of interference, not only for the first but second language e.g. in Tamil students get confused word order and the characters in Mandarin are divergent to English. The educational authorities should therefore provide specialized training for these English Teachers.

\section{Role of Malay and English as the second or third language}

The low proficiency of English can be improved if we change English into the medium of instruction. Of course, such a drastic move would be politically unacceptable. Perhaps we can use 2 languages, Bahasa Melayu an official language and English as the informal official language as two acceptable mediums of instruction in Malaysia. The issue of English as the second language or in practice a third or fourth language for non Malay students needs to be clarified too. The English divide between the urban and rural students is really wide and getter wider by the year ( Gaudart cited in The Star 3.1.2001).The government after proclaiming Bahasa Melayu the official language made English the second language but the latter becomes the third or fourth and even a foreign one to students of different ethnic backgrounds. Hence if this distinction is made less confusion arises especially in the rural context. If it cannot function as the second language effectively, perhaps it can be made into an effective foreign language like Arabic which has been successful as many Malay students can speak and use it. This may help to improve the proficiency level of English especially in rural areas.

\section{Implication}

The result for this study calls for a better understanding of the reasons why rural students cannot excel in their performance in English examinations. The Ministry of Education must plan the special training of English teachers to teach in rural schools as the learning situation is different from urban areas. 
On the basis of this study, 2 suggestions are needed

1. The need for an effective English teaching methodology in rural schools

2. The role of school culture in the learning of English in rural schools

\section{References}

Asmah Haji Omar, (1992).The linguistic scenery in Malaysia. Kuala Lumpur. Dewan Bahasa dan Pustaka.

Bahiyah, A.H (1992) Malu-shyness behavior in the English language classroom. The English Teacher, 12, 97105.

Chandrasegaran, A. (1979). Problems of learning English in national schools in Johor, Malaysia: An investigation of attitudinal motivational variables learning strategies and exposure to English. Unpublished M.A Dissertation, University of Singapore

Chandrasegan A, (1980). Problems of learning English as a second language. An investigation of factors affecting the learners of ESL in Malaysia. SEAMEO, Regional Center Singapore: Singapore University Press.

Dulay, H., Marina B.\& Stephen K. (1982). Language Two. New York: Oxford University Press.

Gardner, R.C (1960). Motivational variables in second language acquisition In R.C. Gardner \& W. E. Lambert (1972).Attitudes and motivation in second language learning, (199-216). Rowley, Massachusetts: Newbury House Publishers

Fotos, S.S. (1991). The cloze test as an integrative measure of EFL proficiency. A Substitute for Essays or College Entrance Examinations Language Learning, 41/3 313-336

Jayatilaka, T.D. (1982). Motivational and attitudinal variables in the learning as a second language: A study of Malaysian University students. PhD Thesis. University of Michigan, United States of America.

Mackay, W.F. (1965). Language Teaching Analysis. London: Longman, Green and Co.

Murdock, G.P. (1965). Social Structure New York: The Free Press

Musgrave, P.W. (1972). The Sociology of Education London: Methnen \& Co Ltd

Patton, M \& Q. (1996) Qualitative Evaluation and Research Methods Newbury Park, California: Sage.

Rosli \& Malachi, E (1990). A comparative study of the achievement and the proficiency levels in English as a second language among learners in selected rural and urban schools in Peninsular Malaysia, The English Teacher, XIX, 48-56.

Spolsky, B. (1969). Attitudinal aspects of second language learning Language Learning. 19, 271-283.

The New Sunday Times. 28 January 2000.

The Straits Times. 12 September 2000.

The Star. 10 February 2000.

The Star. 12 July 2000.

The Star. 22 December 2000.

The Star. 8 November 2000.

The Star. 10 November 2000.

The Star. 3 January 2001.

Thevanathampillai \& Baba, T.L. (1984). Student variables in second Language Learning. RELC Journal, Vol $15 / 1,50-63$.

Zimbardo, P.G. (1977). Shyness can be quiet yet devastating problem. Language Learning, 6, 68-70. 
Schematic Representation of Gardner's 1979 Social Education Model Figure 1

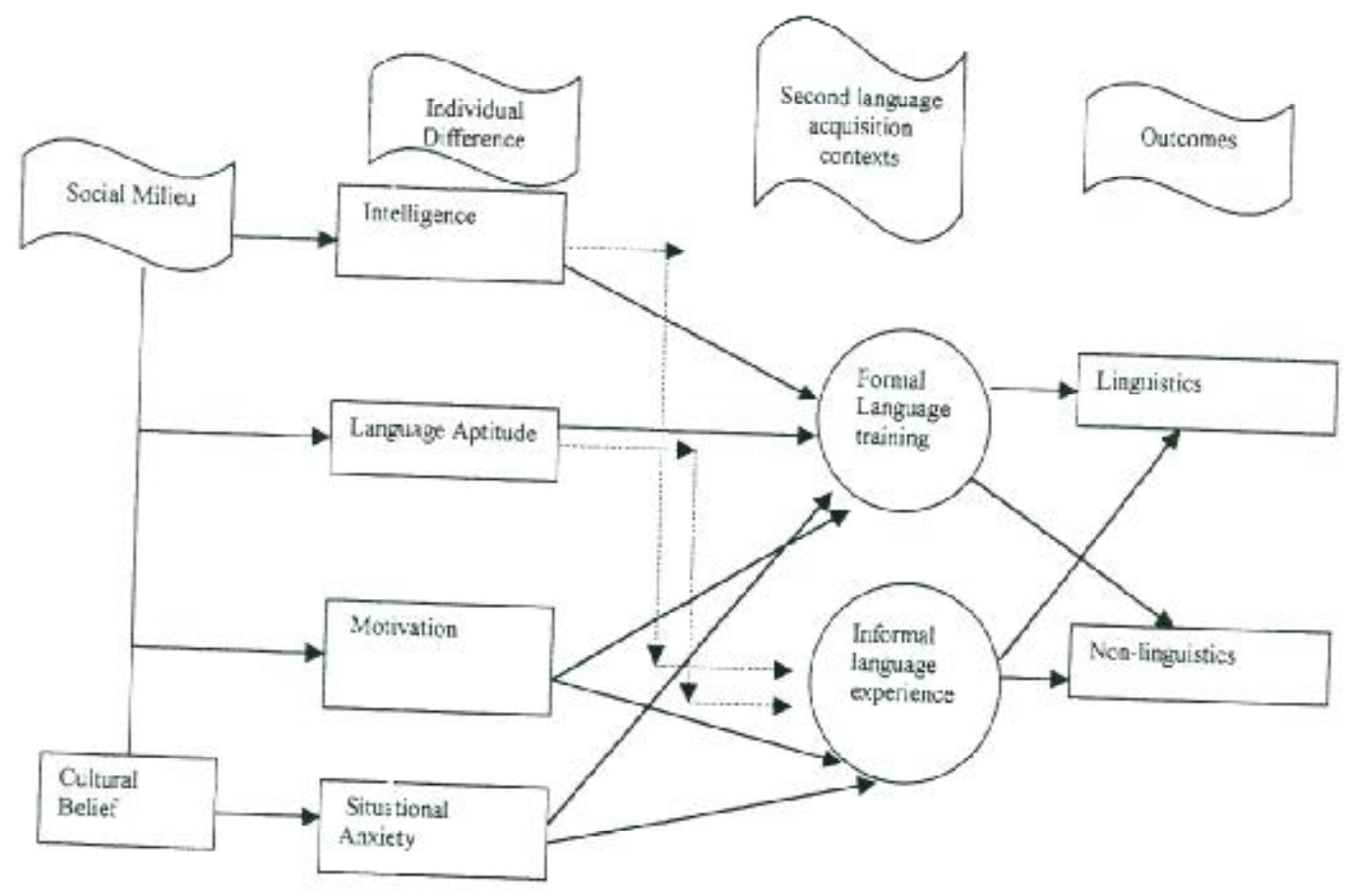




\section{Schematic representation of Gardner \& MacIntvre's Social education Model 1993}

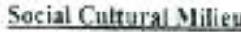
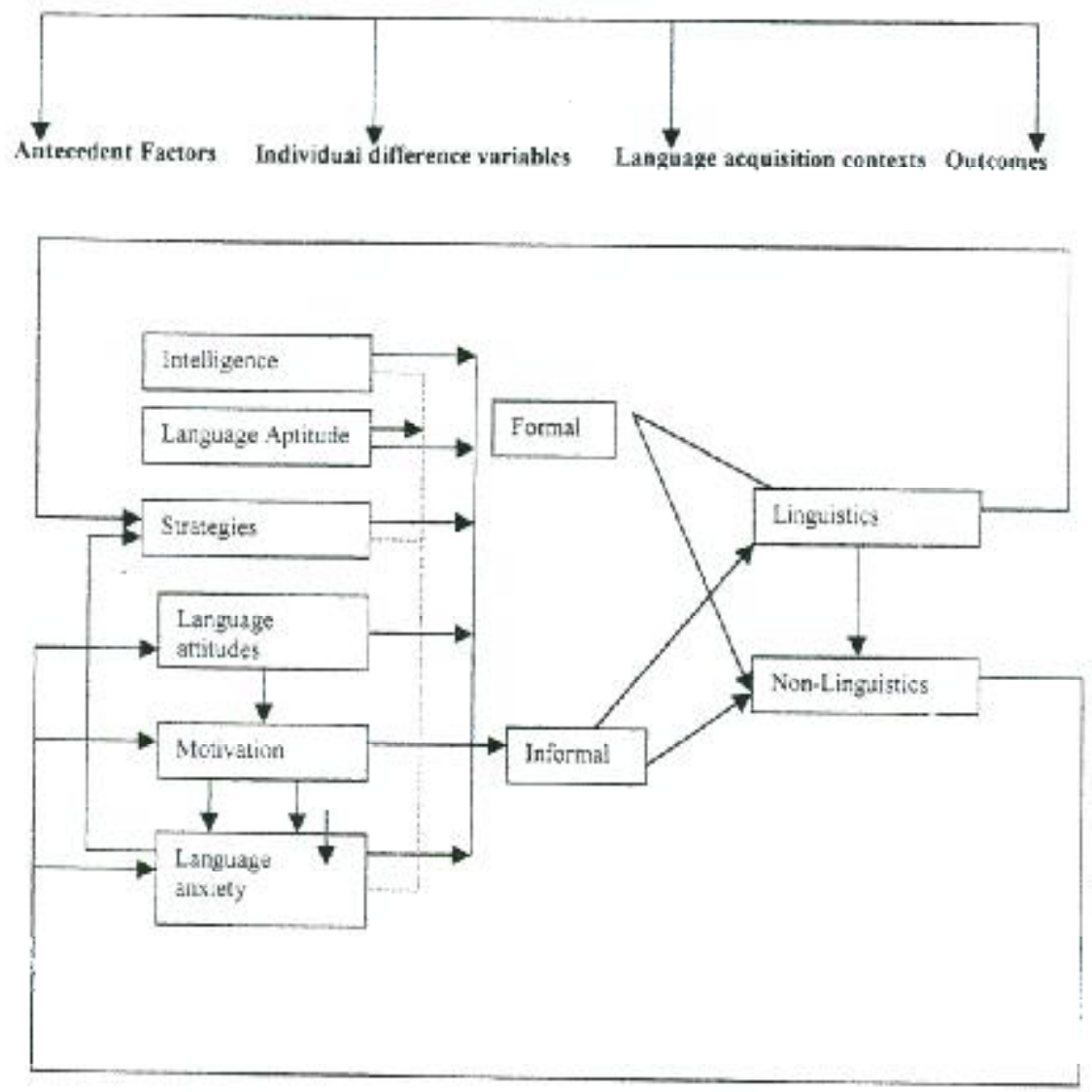

Figure 2 


\section{Appendix A: Interview checklist}

The following questions were used in the interviews for students.

1. Why do you think English is important?

2. Do you think students should learn English?

3. How do you go about learning English?

4. What do you think are some problems in learning English?

5. What ways can you suggest fir a student in rural school to learn English?

6. Compared to your peers elsewhere especially in the urban areas, what do you think the rural school lacks?

7. Do you think that students learn English because of examinations?

8. How do you defend yourself if you are accused of not being interested to learn English? Why?

9. Do you think the school culture helps you in learning English?

10. Do you agree that the "rural cultural factor" hinders the learning of English in the rural areas? Note that examples of rural cultural factors like non English speaking environment, peer pressure etc was not given.

11. Who in your opinion should be blamed for the failure of motivation to learn English in your school? Why?

12. Do you blame the lack of exposure as one of the problems for poor proficiency in rural area?

13. What do you think are other issues that can be considered to have influence the learning of English in your school or in the East coast at large?

\section{Appendix B: Questionnaire for teachers}

Background Name:

Qualification:

Classes taught:

Years of experience:

1. Why do you think English is important here?

2. Do you think students should learn English?

3. What are the problems you encounter in teaching English in the rural setting?

4. How do you go about teaching English in the rural setting?

5. What are the ways you can make a student interested in English?

6. Compared to the teachers in urban areas, what do you lack here to help in the teaching of English?

7. Do you agree that the rural cultural factor e.g. peer pressure, rural school culture) hinders the acquisition of better proficiency level of students?

8. Do you think you teach English for exam purposes or for other reasons?

9. Do you think the school culture (non-English speaking environment) helps you in the teaching of English in the rural areas?

10. Who should be blamed if the students fail to be proficient?

11. What other issues can you think of which may influence the learning and teaching of English in the rural areas? 
In the following passage, each of the numbered blanks stands for one word that has been omitted. Read the passage right throngh and then fill each blank with one word. Choose the word that you think would best fill the blank. The first blank has been filled for you.

\section{Passage 1}

When dinner-time arrives, we begin to feel hungry. Our bodies let us know that we are in need of food. For example, there are hunger pangs $(0)$ in our stomachs. If ... (1) tasty food is given...(2) us, our mouths water. ......(3) is a sign....(4) it is time to .....(5).

Eating food can be...(6) great pleasure. Beside, this...(7) a busy important part...(8) our daily activity. Our...(9) need food and water...(10) day. Every living cell...(11) have some food from...(12) to time, otherwise we...(13) no longer live. The...(14) we eat is changed...(15) form before it reaches...(16) body cells. This changes...(17) place in our stomachs...(18) change all the solids...(19) liquids and remove ....(20) waste material in the food we have swallowed. In other words, our organs digest the food.

\section{Passage 2.}

Bukit Takun is a limestone hill near Kuala Lumpur. It has a height of about (0) 380 to 400 meters...(1) a circumference of more...(2) 200 meters. Its magnificence... (3) a landmark draws attention...(4) every passer-by. Some of ...(5) animals and plants found....(6). Takun are very rare... . (7) example, goat, antelopes...(8) as serows live here...(9) they are now threatened...(10) extinction. Even some plants...(11) grow here can only .... (12) found in Malaysia but nowhere else. 
Near Bukit Takun...(13) another hill which is ...(14) Anak Takun. This smaller hill...(15) an intricate network...(16) limestone caves which are...(17) of unique formations. Visitors...(18) these caves should find...(19) interesting to explore them. .....(20) few people know about the rewarding experience that awaits them.

Section B.

In each of the questions below, four parts are underlined and marked A, B, C or D.

One of these parts contains an error. Decide whether it is A, B, C or D.

1.My mother is such a good cooker that she is always called upon to use her cooking

A $\mathrm{B}$ C

skills when there are weddings and birthday parties.

D

2.Despite of many strong objections from his relatives, Subramanian took over the family A.

B

C

business when his father passcd away last month.

D

3. When 1 arrived home after work, I was horrified to discover that somebody had broken A B

into my house and take all my valuables.

D

4.The brown box which arrived at the railway station was $\leqq$ heavy that either Amin nor Bala could lift it.

A B $\quad$ C

D

5.Please give my regards to your parents and convey my thanks to them for their warm A

B

C 
hospitality, when I stay as a guest in your house last week.

D

6. We are very grateful to Encik Ismail, the State Career officier, for come to the school to A

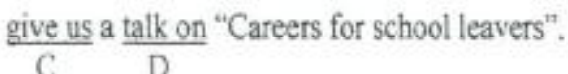

7 To my opinion, boys, too, should learn to cook as it is important that they know how to A B

prepare a simple meal if the need arises.

D

8.Please told your mother that Mrs. Lee rang up to inform that she would not be able to A B

take her to the office tomorrow

D

9.Members of the floor, I strongly opposed the motion that television does more harm A B

$\mathrm{C}$

than good in the world today.

D

10.Zainal turned to face the man who suddenly takes out a knife from his pocket and A B C

pointed it at him.

D 
Answers to the Cloze Test

\begin{tabular}{|c|c|}
\hline Passage 1 . & Passage 2 \\
\hline 1.some & 1. and \\
\hline 2.10 & 2. than \\
\hline 3.This & 3.as \\
\hline 4. that & $4, t 0$ \\
\hline 5.eat & 5 the \\
\hline 5 a & 6 on \\
\hline 7 plays & 7.for \\
\hline 8.in & 8. known \\
\hline 9.bodies & 9 .but \\
\hline 10.every & 10.with \\
\hline 11.must & 11. that \\
\hline 12.time & 12.be \\
\hline 13.can & 13.15 \\
\hline 14.food & 14. calledinamed \\
\hline 15.in & 15.has \\
\hline $16.0 u r$ & 16 of \\
\hline 17.takes & 17 full \\
\hline 18.They & 18.70 \\
\hline 19 into & $19 \mathrm{it}$ \\
\hline 20.the & 20. Very \\
\hline
\end{tabular}

Answers to the Enror Identification questions.

1A 2A 3D 4C 5D 6B 7A 8A 9C 10B 